\title{
The Relationship between Ethical Work Climate and Organizational Innovation
}

\author{
Adibah Abdul Kadir ${ }^{1}$, Fadillah Ismail ${ }^{2}$, Asad Khan ${ }^{3}$, Adnan Ali Hassan Humaid AlHosani ${ }^{4}$, \\ Nor Syafiqah Izzati Zaidi ${ }^{5}$ \\ \{adibah_kadir@yahoo.com¹, fadillah@uthm.edu.my², asadkhan818@yahoo.com³ \\ 1,2,3,4,5Faculty of Technology Management and Business, Universiti Tun Hussein Onn Malaysia
}

\begin{abstract}
In the era of globalization today, ethics have become a concern in researching due to the level of growth in innovation. This study has examined the level of ethical work climate and the level of organizational innovation among researchers (academic staff) at University XYZ. Furthermore, this study has determined the relationship between ethical work climate and organizational innovation. This study has applied a quantitative approach to collect data using a survey questionnaire and analyzed through SPSS to find results. This study has distributed 470 questionnaires among the academic researchers in all faculties at University XYZ. Based on the results, it has found that researcher (academic staff) at University XYZ has a sound ethical work climate practices while conducting research. Meanwhile, respondent's implementation towards innovation while doing their research is moderate. Besides, the study has noted a positive correlation and significant relationship between ethical work climate and organizational innovativeness among researcher (academic staff). It indicates that a positive ethical work climate leads to putting positive influences on organizational innovativeness.
\end{abstract}

Keywords: Ethical work climate, organizational innovation, researchers, quantitative approach.

\section{Introduction}

Development of the Industrial Revolution 4.0 (RI 4.0) has a direct impact on various areas, including education, which is the base of the workforce provider, as the new industrial revolution requires a new set of skills. As a result, this training and education system can grow in tandem that providing industry the skilled labor to support the current industry development [1].

The challenge of Industry 4.0 or the Fourth Industrial Revolution, university students must be out of habit [2]. Cognitive flexibility is indispensable, so complex issues are dealt with aggressively and holistic as one example from ethical aspects. "As leaders and members of their team need to strengthen themselves for the complex problem solving across disciplines thoroughly requires excellent teamwork, as a leader and team member. In addition to technical knowledge, charisma and leadership innovate recipes teamwork success "[2]. In the view of perspective academic staff member, who is involved in research, faces complex issues, especially the work ethical climate. Hence, positive climate work ethics practices need to be established to achieve an excellent outcome.

\subsection{Research background}

As a researcher at the university, some issues need to be addressed, solve and consider for improvement purposes. Ethical work climate has rarely discussed in innovation even though 
the success of an organization has identified with the importance of innovation. Along with that, an ethical work climate can be enhanced through innovation within an organization. Logically, as a researcher in an organization, they will have to deal with ethical problems usually which is moral.

It often happens when the organization is innovating, individuals' performance is not impacting by organizational ethics, but everyone else performance in the organization is impacting by organizational ethics [3]. This explanation means two different things which are it could mean the individual believes it is acceptable to ignore organizational ethics to increase their performance or it could the individual believes the ethical climate only helps the organization's overall performance but not individual's performance.

Organizational innovation performance is backed and affected by organizational culture [4]. Additionally, some researchers point out that the organizational climate has a unique significance to reveal innovative work behaviors [5].

Generally, at the university level, innovation is essential, because innovation is to look beyond the work done and develop new ideas that can help the job done in a new way. The purpose of each invention is from what we have been doing, and we create to something different in either quantity or quality or both.

By adopting a positive climate work ethic, it can manifest an organization's innovative indirectly in terms of skill and expertise. From there, the existence of positive ethical work climate of workers can be nurtured and make improve workers performance. Therefore, this study investigates the relationship between ethical work climate and organizational innovation among researchers at University XYZ.

\subsection{Problem statement}

At university, the code of ethics is often giving warning to staff to prevent them from doing the practice of violating university code of ethics. There have been warnings yet, but there is still some staff who is looking for angle cuts that they want to engage in doing unethical acts or violate regulations set by the university.

A study was conducted in Anambra State at the university and the purpose of the study was to find out the unethical evaluation practices among academic staff. Through the research findings, it was found that the unethical practices were rare among academic staff [6].

Most of the study are focusing on work ethics conducted by the researches of previous studies. Hence, in this study, the relationship between ethical work climate and organizational innovation will be investigated and perform in a limited area which is faculties in University XYZ. A limited area such as faculties gives influence in understanding the relationship between ethical work climate and organizational innovation which cover sample data among researchers (academic staff) at University XYZ.

\subsection{Research objectives}

To investigate the level of ethical work climate and the level of innovation among researchers at University XYZ. To identify the relationship of ethical work climate and the organizational innovation among researchers at University XYZ.

\subsection{Significance of the study}

This research is about the ethical work climate where researcher practices and their perception about this ethical work climate. Good ethics can give an effect that is in term of goods effect lead to ethical work climate in practice. Viewed in individual perspectives with 
practicing good ethical work climate, it enhances their performance because their thinking will be more creative in giving ideas followed by good decision-making. Furthermore, this leads to an increase in performance.

While viewed in the perspective of an organization, there will be practice improvement in ethical work climate practice. Hence, this makes an organization is knowledgeable and more understanding each other and excellent in decision-making.

Besides, this research of ethical work climate and organizational innovation that was conducted in University XYZ. can be a reliable reference for the future or one of the contributions to other universities in Malaysia. This is because other researches revealed with the solution of a new way to improve their ethical work climate practice and be knowledgeable and more understanding, especially in decision-making.

Finally, innovation will be determined through the ethical work climate that after conducting this investigation. By this research, the ethical work climate will be as the factor of the organizational innovation. Hence, it can be as the reference to the future to improve their ethical work climate and organizational innovation.

\subsection{Scope of the study}

The topic of this research is the relationship between ethical work climate and organizational innovation among researchers at University XYZ. Academic researchers of University XYZ were selected as respondents. The researcher defined as professionals engaged in the conception or creation of new knowledge, products processes, methods, and systems and in the management of the projects concerned [7].

The six faculties are Faculty of Civil and Environmental Engineering (FKAAS), Faculty of Electrical and Electronic Engineering (FKEE), Faculty of Mechanical and Manufacturing Engineering (FKMP), Faculty of Technology Management and Business (FPTP), Faculty of Technical and Vocational Education (FPTV), Faculty of Computer Science and Information Technology (FSKTM).

Under ethical work climate, the investigation will through these three elements which are caring climate and independent climate [8] and mastery climate [9] while under the organizational innovation the investigation will through strategic innovation, behavioral innovation and innovative decision making [9].

Data was collected from all faculty members of the University XYZ. The investigation has only focused on ethical work climate and organizational innovation. The population is 602 with a sample size of 465 .

\section{Literature review}

\subsection{Ethical work climate}

The ethical climate in the organization describes the environment of the workplace and the moral atmosphere in the workplace and practice (ethical level) within the organization [10]. This should be emphasized in the business as it can create a positive environment and can indirectly have a positive influence (progress in achieving the goals to make). Generally knowing there are five types of ethical climate that have the potential to exist (in terms of positive) are like peace and law, independence, caring, instrumental, and rules.

There is also the possibility of a climate-conducive climate to exist in an organization (in terms of negativity) such as discrimination, harassment, aggression, hostility, and imbalance. 
It is vital to apply positive ethics to use the attitude in each of these workers to be more productive and harmonious.

A Climate Ethical Theory was created by John Cullen and Bart Victor [8]. As they had come up with these theories, they were called as the pioneer researches, and their studies were not only theoretical but also in empirical studies which both are in the classification of the discipline of ethical climate [11]. Ethical climate theory is a concept with high severity among the business ethics [12], this structure expresses an organization's various and diversified climates which are the moralistic inferences and designs portraitures of these concepts to the individuals [13]. Therefore, innovative action needs to take by the organization so that improvement in terms of progress and efficiency in problem-solving at the workplace can be solved wisely, quickly, and smoothly.

\subsubsection{Caring climate}

A caring climate, valuing the collective well-being, inspires more forms of active trust towards the top manager and peers, which promotes commitment to the organization [10]. Research, who found that perceptions of a caring climate were significantly related to enhancing feelings of group connectedness, heightened enjoyment, and more positive attitudes toward classmates and instructors [14]. This finding makes them suggest that a strategy to foster engagement in physical activity courses on campus is to train instructors to value, support, and welcome students. Hence, caring climate practices is part of a cultural approach to ethics.

\subsubsection{Independence climate}

Behavior-based on personal values and convictions allows for individual freedom and responsibility with minimum influence from external forces [15]. This research said that any action by a firm to influence employees' decision making that is contrary to their moral convictions or interferes with their freedom to exercise moral obligation would weaken a climate of independence. It is because the system of human resources can help cultivate a climate of autonomy and can destroy a climate of independence. The examples of environment or organizations of independent climate are new firms and entrepreneur ventures. Independent climate could guide by personal convictions and personal morality [16].

\subsubsection{Mastery climate}

Mastery climate a dimension of motivational climate that supports effort and cooperation emphasizing learning, mastery, and development of skills [17]. Besides, masteryoriented behavior can motivate by self-referential improvement, whereas performanceoriented behavior focuses on performance relative to that of others. The extant research informs us that knowledge hiding is detrimental for creativity, but mastery climate is favorable for creativity and for overriding the negative effects of knowledge hiding [18].

First knowledge hiding might not result in additional knowledge misbehavior because employees stimulated to share knowledge by their mastery achievement structures and the environment of trust among team members [9]. The ethics of a mastery climate allows for significant task modification [19].

\subsection{Organization innovation}

Organizational innovation means that implementation of a new organizational method in the firm's business practices, in the organization of its workplace or its external relations, to 
improve the use of knowledge, workflows efficiency or quality of goods or services. The organizational innovation concept is part of the concept of innovation and development and makes more noticeable of new ideas and the propensity for change within organizations. Organization innovations can increase firm's performance by reducing administrative costs or transaction costs, improving workplace satisfaction (and thus labor productivity), gaining access to non-tradeable assets (such as non-codified external knowledge) or reducing costs of supplies [20].

\subsubsection{Strategic innovation}

Strategic innovation can be defined as the development of new strategies that can help the firm compete with other competitor and at the same time, it can create value for the firm. Without an innovation strategy, innovation improvement efforts can quickly become a grab bag of much-touted best practices: dividing R\&D into decentralized autonomous teams, spawning internal entrepreneurial ventures, setting up corporate venture-capital arms, pursuing external alliances, embracing open innovation and crowdsourcing, collaborating with customers, and implementing rapid prototyping [21].

An explicit innovation strategy helps design a system to match specific competitive needs. Therefore, without an innovation strategy, different parts of an organization can easily wind up pursuing conflicting priorities even if there is a clear business strategy. For example, they found that in high-tech industries, an innovation strategy of 'new product targeting existing markets' and 'improved product targeting new markets' was less effective for increasing sales growth than 'improved product targeting existing markets.' However, in the case of medium-high tech industries, an innovation strategy of 'new products targeting in existing markets' was the most effective strategy.

\subsubsection{Behavioural innovation}

Employee behavior, focused on the generation, introduction, and application (within a role, group or organization) of new ideas, processes, products or procedures, intended to benefit the relevant unit of adoption [22]. Examples of innovative employee behavior in the workplace include introducing new technologies and techniques, suggesting new ways to achieve objectives, trying new means of performing work tasks, and facilitating the implementation of new ideas.

Besides, innovative behaviors include not only those behaviors leading to innovations within the individual's work role but also behaviors that initiate or facilitate innovations in higher-level units such as the individual's workgroup, department, or the entire organization.

\subsubsection{Innovative decision making}

Innovative Decision Making (IDM) is an individualized, self-assessment, and workshopbased methodology, which addresses the universal need of business how to arrive at the best decisions [9]. IDM can be applied to optimize decision-making and problem-solving. For example, an organization, everyone would have different opinion and understanding and with all the view are speak out, one decision must be made. As we can see, there would be an innovative decision making in choosing what the best opinion is. 


\subsection{Conceptual Framework}

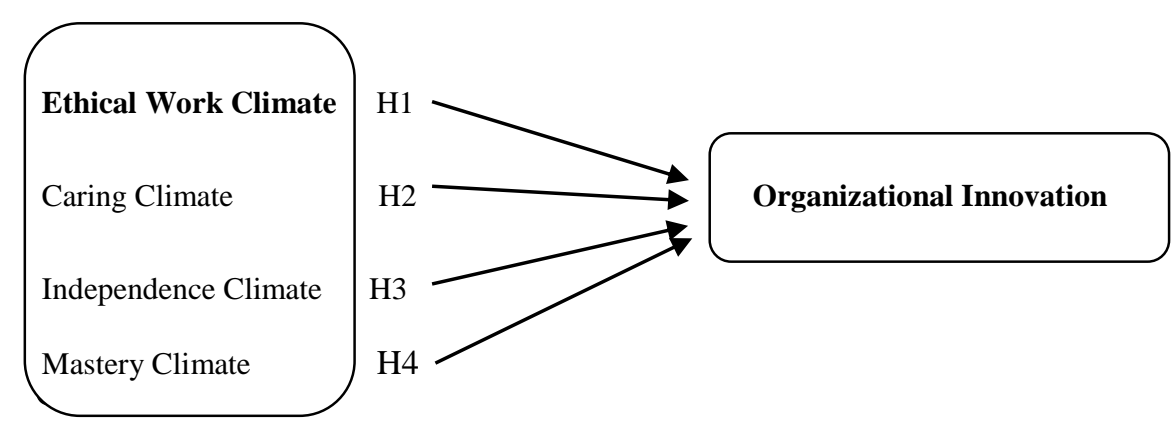

Fig. 1. Conceptual framework of the relationship between ethical work climate and organizational innovation.

\section{Hypotheses:}

H1: There is a significant relationship between ethical work climate and organizational innovation.

H2: There is a significant relationship between caring climate and organizational innovation.

H3: There is a significant relationship between independence climate and organizational innovation.

H4: There is a significant relationship between mastery climate and organizational innovation.

Victor and Cullen (1988), develop ethical Work Climate of caring climate and independence climate, and mastery climate is a researcher from, Hernaus et al. [9] while in organizational innovation, strategic innovation, behavioral innovation, and the innovative decision making are from researcher Hernaus et al. [9].

The dependent variables (strategic process, behavioral innovation, innovative decision making) in this study only concentrate among researcher (academic staff) in UTHM Batu Pahat.

\section{Methodology}

\subsection{Research design}

This study has applied the quantitative method. The quantitative method involves statistical, numerical or mathematical analysis of data that means that it is using the scientific method and is more reliable [23]. The survey method was applied to collect data from the academic staff of UTHM Batu Pahat. The study has purposed to examine the relationship between ethical work climate and organizational innovation.

\subsection{Instruments}

There are two types of research techniques which are qualitative and quantitative. The nature and availability of the required information and the purpose of study are three factors that influence in deciding which type of research will carry out. Quantitative methods typically involve writing a question for surveys and in-depth interviews, learning to quantify or count responses, and statically (mathematically) analyzing archival, historical or our data and a standard form is a self-administered questionnaire. 
As the quantitative method is most suitable for this research, it will be used for investigation. Therefore, selection to distribute questionnaires online and face to face to the researchers (academic staff) University XYZ of all faculties was used.

The questionnaire is constructed based on the independent variables, dimensions of ethical work climate which are caring climate, independence climate formulates [8] and mastery climate [9] and the dependent variables, dimensions of organizational innovation which are strategic innovation, behavioral innovation and innovative decision making [9]. Means the questionnaire has three sections which are Section A: Demographics, Section B: Dimensions of Ethical Work Climate and Section C: Dimensions of Organizational Innovation.

A 5-point Likert Scale was used for data collection which ranges from Strongly Disagree (1), Disagree (2), Neutral (3), Agree (4), Strongly Agree (5).

\subsection{Population and sample}

The population of this research is 602 researchers (academic staff) from all six faculties in University XYZ. Meanwhile, the sample size is 469. Krejcie \& Morgan [24] method is used to determine sample size [24]. The techniques sampling used is stratified sampling. Below Table 1 shows the population and sample size of each six faculties in University XYZ.

Table 1. Population and sample size of each faculty in UTHM Batu Pahat

\begin{tabular}{lcc}
\hline \multicolumn{1}{c}{ Faculty } & Population & Sample Size \\
\hline FKASS & 125 & 94 \\
FKEE & 135 & 100 \\
FKMP & 136 & 101 \\
FPTP & 80 & 66 \\
FPTV & 72 & 61 \\
FSKTM & 54 & 47 \\
Total & 602 & 469 \\
\hline
\end{tabular}

\subsection{Pilot test}

Table 2. Rule of Thumbs for Cronbach's Alpha Value [25]

\begin{tabular}{cl}
\hline Alpha Value, $(\alpha)$ & \multicolumn{1}{c}{ Level } \\
\hline$>0.9$ & Excellent \\
$>0.8$ & Good \\
$>0.7$ & Acceptable \\
$>0.6$ & Questionable \\
$>0.5$ & Poor \\
$<0.5$ & Unacceptable \\
\hline
\end{tabular}

Thirty respondents participated in testing the credibility of the question in the questionnaire. A pilot test was conducted to increase the quality of research question before the research was conducted. Table 3 below shows the result value of Cronbach's alpha for the pilot test. 
Table 3. Pilot Test Result

\begin{tabular}{llcc}
\hline \multicolumn{1}{c}{ Elements } & $\mathrm{N}$ & $\begin{array}{c}\text { Cronbach's alpha } \\
(\mathrm{N}=30)\end{array}$ \\
\hline IV & Caring climate & 7 & 0.838 \\
& Independence climate & 4 & 0.906 \\
& Mastery climate & 5 & 0.908 \\
DV & Strategic innovation & 3 & 0.501 \\
& Behavioral innovation & 4 & 0.878 \\
& Innovation decision making & 4 & -0.886 \\
\hline
\end{tabular}

From Table 3, one of the independent variables which are caring climate shown the good level (based on Table 2) with Cronbach's Alpha of 0.838. The other two independent variables which are independent climate and mastery climate shown the excellent level (based on Table 2) with Cronbach's Alpha of 0.906 and 0.908.

Meanwhile for dependent variables, one of its which is strategic innovation shown the poor level (based on Table 2) with Cronbach's Alpha of 0.501. The other two dependent variables which are independent climate and mastery climate shown good level (based on Table 2) with Cronbach's Alpha of 0.878 and 0.886. Overall both variables are valid and reliable based from the Rule of Thumbs by George and Mallery [25] Cronbach's Alpha because of the from result pilot test (Table 3) shown the value is above 0.50 .

\section{Data analysis and result}

\subsection{Introduction}

In this study, questionnaires have been distributed to the researchers (academic staff) at University XYZ. Questionnaires that have distributed to researchers (academic staff) are about 470 questionnaires. Not all questionnaires have answered and returned to the researcher. The response rate is $69 \%$. In this chapter, respondent profile's analysis, result, and data analysis of The Relationship between Ethical Work Climate and Organizational Innovation among Researches at University XYZ that include reliability analysis, descriptive analysis, normality test, and correlation analysis were discussed. All the data had been completely analyzed using SPSS software.

\subsection{Questionnaire analysis}

The researcher has distributed the questionnaire to 465 respondents, but only 294 questionnaires that are successfully collected. Therefore, the data analysis is based on 294 questionnaires. Table 4 below shows the analysis rate return.

Table 4. Analysis rate of return

\begin{tabular}{lccc}
\hline Faculty & Population & $\begin{array}{c}\text { Sample } \\
\text { Size }\end{array}$ & Respondent \\
\hline FKASS & 125 & 94 & 66 \\
FKEE & 135 & 100 & 71 \\
FKMP & 136 & 101 & 72 \\
FPTP & 80 & 66 & 46 \\
FPTV & 72 & 61 & 41 \\
FSKTM & 54 & 47 & 28 \\
Total & 602 & 469 & 324 \\
\hline
\end{tabular}


Distribution of the questionnaire is 465 (100\%). The returned questionnaire by the respondent is $324(69 \%)$. Overall the returned questionnaire is valid. Hence respondent rate is $69 \%$.

\subsection{Demographic of respondent}

Demographic information regarding respondents obtained through questions posed in Section A of the questionnaire. The descriptive method that is frequency and percentage used to analyze the information of the respondent's demographic which, gender, age, and race.

Table 5: Demographic of Respondent

\begin{tabular}{lrr}
\hline \multicolumn{1}{c}{ Category } & Frequency & Percentage $(\%)$ \\
\hline Gender & & \\
Male & 141 & 41.16 \\
Female & 183 & 58.84 \\
& & \\
Age & & \\
$21-30$ & 43 & 11.22 \\
$31-40$ & 152 & 48.30 \\
$41-50$ & 73 & 31.63 \\
$51-60$ & 36 & 8.84 \\
& & \\
Race & & 68.37 \\
Malay & & 19.05 \\
Chinese & 221 & 11.90 \\
Indian & 50 & 0.68 \\
Other & 45 & \\
\hline
\end{tabular}

Table 5 above indicate the gender of 294 respondents. From 294 respondents, about 121 $(41.16 \%)$ of them were male, and $173(58.84 \%)$ of them were female. The age of respondents ranging into four categories namely 21-30 years old, 31-40 years old, 41-50 years old, and 5160 years old. However, the majority of the respondents were coming from the age group 31 to 40 years old. The finding further indicates that most researchers are adults and matures ages. Based on the table above, the majority of the respondent are Malay which compromises of 201 respondents or $68.37 \%$. There are also 56 Chinese respondents $(2 \%)$, and 35 respondents represent Indian $(11.90 \%)$. Only 2 respondents represent other race $(0.68 \%)$.

\subsection{Reliability test}

Reliability analysis is used to test consistency. Cronbach's Alpha was used to determine the internal reliability. The value range of reliability was from 0.0 to 1.0 , the higher the value of Cronbach's Alpha, which means the more reliable the instrument. The value of Cronbach's Alpha internal consistency table referred was as shown in Table 6 below. The data collected and analyzed using Statistical Package for the Social Science (SPSS) software. 
Table 6. Reliability Analysis Result

\begin{tabular}{llccc}
\hline & & \multicolumn{2}{c}{ Reliability } \\
\cline { 3 - 5 } & Cronbach's Alpha & $\begin{array}{c}\text { Cronbach's Alpha } \\
\text { Based on the } \\
\text { standardized item }\end{array}$ & N of item \\
\hline \multicolumn{1}{c}{ Overall } & 0.927 & 0.929 & 27 \\
\hline IV & Caring climate & 0.865 & 0.865 & 7 \\
& Independence climate & 0.841 & 0.841 & 4 \\
MV & Strastery climate & 0.862 & 0.862 & 5 \\
& Behavioral innovation & & & 3 \\
& Innovation decision making & 0.704 & 0.704 & 4 \\
\hline
\end{tabular}

Table 6 above shows the reliability of the research. The overall Cronbach's Alpha scored 0.927 which is an excellent level. This questionnaire consisted of 27 items with 5 Point-Likert scale type. For the caring climate, the Cronbach's Alpha scored is 0.864 with no item deleted and considered as good level with seven items.

The Cronbach's Alpha for independence climate scored is 0.840 with four items, and there is also no item deleted. It is considered a reasonable level. However, for item mastery climate, the Cronbach's Alpha is 0.861 with five items, and there is also no item delete. These items are considered as good level based on Table 6 .

Next is the dependent variable with items strategic innovation, behavioral innovation, and innovation decision making. The items strategic innovation has scored 0.698 Cronbach's Alpha with three items and no item deleted. Based on Table 6, it is considered as questionable level. Meanwhile, for item behavioral innovation, the Cronbach's Alpha scored is 0.882 with four items and also no item deleted. It is considered a good level based on Table 7. However, for item innovation decision-making, it has 0.897 Cronbach's Alpha with four items and no item deleted. Based on Table 6, this item is considered as a good level.

\subsection{Descriptive analysis}

Descriptive statistics refers to statistics that describe the phenomena of interest. This includes the frequency of a specific event occurring, the average score when a set of figures is involved, as well as the extent variability in the set (the central tendencies and dispersions of the independent and dependent variables). There are three measures of central tendency, the mean, median and mode [26]. This section involved frequency, percentage and mean score. Table 7 shows the extent level of mean developed by as shown below.

Table 7. Extent Level of Mean (Tasmin \& Wood, 2008)

\begin{tabular}{cl}
\hline Range & \multicolumn{1}{c}{ Level } \\
\hline $1.00-2.23$ & Low \\
$2.34-3.67$ & Moderate \\
$3.68-5.00$ & High \\
\hline
\end{tabular}




\subsubsection{Objective 1: To investigate the level of ethical work climate and the level of organizational innovation among researchers at University XYZ}

To achieve the first objective in this research which is to investigate which type of Ethical Work Climate that most researcher (academic staff) perceive as factors that drive them to innovate and which type Organizational Innovations that most researcher (academic staff) innovate. The dimension of Ethical Work Climate in Section B has about 16 items of the questionnaire had been asked to the respondent. Each variable is basing on three dimensions of ethical work climate namely, Caring Climate, Independence Climate, and Mastery Climate. For the dimension of Organizational Innovation in Section C, 11 items of the questionnaire have asked the respondent.

Each variable is basing on three dimensions of organizational innovation namely Strategic Innovation, Behavioural Innovation, and Innovative Decision Making. The mean score is analyzing to determine the total score on each item and dimensions. The findings of this part are analysed to identify whether the implementation of ethical work climate is level of low, moderate or high (based on Table 7) and to determine whether the organizational innovativeness among researcher (academic staff) in University $\mathrm{XYZ}$ is at level of low, moderate or high (based on Table 7).

\subsubsection{Caring climate}

Table 8 below shows the frequency of a caring climate. The first dimensions of ethical work climate consist of 7 questions presented in Section B. The mean score for each statement had a range from 3.83 to 4.28 . Among these statements, the 1st statement had the highest mean score which is 4.28 . This is because research institute can prevent dissatisfaction in an organization that leads to low outcome out of their research.

Table 8. Frequency of caring climate

\begin{tabular}{|c|c|c|c|c|c|c|c|c|}
\hline \multirow{2}{*}{ No. } & \multirow{2}{*}{ Caring Climate } & \multicolumn{5}{|c|}{ Frequency $(\%)$} & \multirow{2}{*}{ Mean } & \multirow{2}{*}{ Leve } \\
\hline & & VD & $\mathrm{D}$ & $\mathrm{N}$ & $\mathrm{A}$ & VA & & \\
\hline 1 & $\begin{array}{l}\text { The most important concern } \\
\text { is the good of all people in the } \\
\text { company. }\end{array}$ & 0.7 & 0.7 & 14.7 & 38.0 & 46.0 & 4.28 & High \\
\hline 2 & $\begin{array}{l}\text { Our major consideration is } \\
\text { what is best for everyone in } \\
\text { the organization. }\end{array}$ & 0.7 & 4.0 & 16.0 & 40.7 & 38.7 & 4.13 & High \\
\hline 3 & $\begin{array}{l}\text { In this organization, our } \\
\text { major concern always what is } \\
\text { best for the other person. }\end{array}$ & 1.3 & 6.0 & 25.3 & 42.7 & 24.7 & 3.83 & High \\
\hline 4 & $\begin{array}{l}\text { In this organization, people } \\
\text { look out for each other's good. }\end{array}$ & 0.7 & 2.0 & 29.3 & 44.0 & 24.0 & 3.89 & High \\
\hline 5 & $\begin{array}{l}\text { The most efficient way is } \\
\text { always the right way in this } \\
\text { organization. }\end{array}$ & 0.7 & 2.0 & 28.7 & 50.0 & 18.7 & 3.84 & High \\
\hline 6 & $\begin{array}{l}\text { In this organization, each } \\
\text { person is expected above all } \\
\text { to work efficiently. }\end{array}$ & 0.7 & 1.3 & 24.7 & 54.0 & 19.3 & 3.90 & High \\
\hline 7 & $\begin{array}{l}\text { It is expected that you will } \\
\text { always do what is right for the } \\
\text { public. }\end{array}$ & 0.7 & 2.0 & 18.0 & 46.7 & 32.7 & 4.09 & High \\
\hline \multicolumn{7}{|c|}{ Total means score } & 3.99 & High \\
\hline
\end{tabular}




\subsubsection{Independence Climate}

Table 9 below shows the frequency of independence climate. The second dimensions of ethical work climate consist of 4 questions presented in Section B. The mean score for each statement had a range from 3.67 to 3.88 . Among these statements, the 1 st statement has the highest mean score which is 3.88. The 1st statement is because personal ethics are typically those that positively impact the experience of others when used to govern an individual's social or business-related behavior.

Table 9. Frequency of independence climate

\begin{tabular}{|c|c|c|c|c|c|c|c|c|}
\hline \multirow{2}{*}{ No. } & \multirow{2}{*}{ Independence Climate } & \multicolumn{5}{|c|}{ Frequency (\%) } & \multirow{2}{*}{ Mean } & \multirow{2}{*}{ Level } \\
\hline & & VD & $\mathrm{D}$ & $\mathrm{N}$ & $\mathrm{A}$ & VA & & \\
\hline 1 & $\begin{array}{l}\text { In this company, people are } \\
\text { guided by their ethics. }\end{array}$ & 1.3 & 4.0 & 21.3 & 52.0 & 21.3 & 3.88 & High \\
\hline 2 & $\begin{array}{l}\text { Each person in this company } \\
\text { decides for themselves what } \\
\text { is right or wrong. }\end{array}$ & 2.0 & $\begin{array}{c}10 . \\
7\end{array}$ & 26.0 & 40.7 & 20.7 & 3.67 & Moderate \\
\hline 3 & $\begin{array}{l}\text { In this company, people are } \\
\text { expected to follow their own } \\
\text { personal and moral beliefs. }\end{array}$ & 0.7 & 4.7 & 28.7 & 44.7 & 21.3 & 3.81 & High \\
\hline 4 & $\begin{array}{l}\text { The most important concern } \\
\text { in this company is each } \\
\text { person's sense of right or } \\
\text { wrong. }\end{array}$ & 1.2 & 4.7 & 26.0 & 47.3 & 20.7 & 3.81 & High \\
\hline & Total mean & score & & & & & 3.79 & High \\
\hline
\end{tabular}

\subsubsection{Mastery Climate}

Table 10 below shows the frequency of mastery climate. The third dimensions of ethical work climate consist of 5 questions presented in Section B. The mean score for each statement had a range from 3.80 to 4.08 . Among these statements, the 1 st statement and 3rd statement have the highest mean score which is 4.08 . This is because the 1 st statement is about an organization the encouragement to work on getting better because there is the motivation that supports cooperation meanwhile $3^{\text {rd }}$ statement is research institute felt to improve their self-reference to get excellent outcome out of their research.

Table 10. Frequency of mastery climate

\begin{tabular}{|c|c|c|c|c|c|c|c|c|}
\hline \multirow{2}{*}{ No. } & \multirow{2}{*}{ Matery Climate } & \multicolumn{5}{|c|}{ Frequency (\%) } & \multirow{2}{*}{ Mean } & \multirow{2}{*}{ Level } \\
\hline & & VD & $\mathrm{D}$ & $\mathrm{N}$ & $\mathrm{A}$ & VA & & \\
\hline 1 & $\begin{array}{l}\text { The organization is encouraging to } \\
\text { work on getting better. }\end{array}$ & 0.7 & 2.0 & 18.0 & 47.3 & 32.0 & 4.08 & High \\
\hline 2 & $\begin{array}{l}\text { In the organization, we encourage } \\
\text { to often shared opinion and ideas. }\end{array}$ & 0.7 & 3.3 & 22.0 & 46.0 & 28.0 & 3.97 & High \\
\hline 3 & $\begin{array}{l}\text { Behave to improve self-referential } \\
\text { to increase knowledge. }\end{array}$ & 0.7 & 1.3 & 15.3 & 54.7 & 28.0 & 4.08 & High \\
\hline 4 & $\begin{array}{l}\text { Everyone will make sure the } \\
\text { organization clear in every meeting } \\
\text { before dismissing. }\end{array}$ & 2.0 & 4.0 & 21.3 & 50.0 & 22.7 & 3.87 & High \\
\hline 5 & Brave to give an initial knowledge & 1.3 & 3.3 & 25.3 & 54.0 & 16.0 & 3.80 & High \\
\hline
\end{tabular}


even it might not result in addition

to knowledge misbehavior.

\subsubsection{Strategic Innovation}

Table 11 below shows the frequency of strategic innovation. The first dimensions of organizational innovation consist of 3 questions presented in Section C. The mean score for each statement have a range from 3.29 to 3.54. Among these statements, the 1st statement has the highest mean score which is 3.54 but in the moderate range. This result shows that top management willing to seize and explore "chancy" growth opportunity even though it takes risks.

Table 11. Frequency of strategic innovation

\begin{tabular}{|c|c|c|c|c|c|c|c|c|}
\hline \multirow{2}{*}{ No. } & \multirow{2}{*}{ Strategic Innovation } & \multicolumn{5}{|c|}{ Frequency $(\%)$} & \multirow{2}{*}{ Mean } & \multirow{2}{*}{ Level } \\
\hline & & VD & $\mathrm{D}$ & $\mathrm{N}$ & $\mathrm{A}$ & VA & & \\
\hline 1 & $\begin{array}{l}\text { Senior executives of the } \\
\text { organization are willing to take } \\
\text { risks to seize and explore } \\
\text { "chancy" growth opportunities. }\end{array}$ & 2.0 & 8.0 & 34.7 & 44.7 & 10.7 & 3.54 & Moderate \\
\hline 2 & $\begin{array}{l}\text { When we see new ways of } \\
\text { doing things, we are last at } \\
\text { adopting them. }\end{array}$ & 5.3 & 12.0 & 38.7 & 36.0 & 8.0 & 3.29 & Moderate \\
\hline 3 & $\begin{array}{l}\text { Senior executive constantly } \\
\text { seeks unusual, novel solutions to } \\
\text { problems via the use of "idea } \\
\text { man". }\end{array}$ & 3.3 & 8.0 & 45.3 & 37.3 & 3.0 & 3.35 & Moderate \\
\hline & Total mean & core & & & & & 3.39 & Moderate \\
\hline
\end{tabular}

\subsubsection{Behavioural Innovation}

Table 12 below shows the frequency of behavioral innovation. The second dimensions of behavioral innovation consist of 4 questions presented in Section C. The mean score for each statement had a range from 3.53 to 3.70 . Among these statements, the 4th statement had the highest mean score which is 3.70. This is because most of the respondent acknowledges that while doing research, they feel more comfortable and there is an existence of better outcome.

Table 12. Frequency of behavioral innovation

\begin{tabular}{|c|c|c|c|c|c|c|c|c|}
\hline \multirow{2}{*}{ No. } & \multirow{2}{*}{ Behavioral Innovation } & \multicolumn{5}{|c|}{ Frequency $(\%)$} & \multirow{2}{*}{ Mean } & \multirow{2}{*}{ Level } \\
\hline & & VD & $\mathrm{D}$ & $\mathrm{N}$ & $\mathrm{A}$ & VA & & \\
\hline 1 & $\begin{array}{l}\text { We get a lot of support from } \\
\text { senior executives if we want } \\
\text { to try new ways of doing } \\
\text { things. }\end{array}$ & 2.7 & 9.3 & 33.3 & 42.0 & 12.7 & 3.53 & Moderate \\
\hline 2 & $\begin{array}{l}\text { In our organization, we } \\
\text { tolerate individuals who do } \\
\text { things differently. }\end{array}$ & 2.0 & 5.3 & 34.7 & 48.7 & 9.3 & 3.58 & Moderate \\
\hline 3 & $\begin{array}{l}\text { We are willing to try new } \\
\text { ways of doing things and seek }\end{array}$ & 0.7 & 6.0 & 30.7 & 50.0 & 12.7 & 2.68 & High \\
\hline
\end{tabular}




\begin{tabular}{lllllllll}
\hline 4 & \begin{tabular}{l} 
unusual novel solutions. \\
$\begin{array}{l}\text { We encourage people to think } \\
\text { and behave in original and } \\
\text { novel ways. }\end{array}$ \\
\hline
\end{tabular} \\
\hline
\end{tabular}

\subsubsection{Innovative Decision Making}

Table 13 below shows the frequency of innovative decision making. The third dimensions of innovative decision making consist of 4 questions presented in Section $\mathrm{C}$. The mean score for each statement have a range from 3.75 to 3.83. Among these statements, the 1 st statement and 4th statement has the highest mean score which is 3.83 . These results show that most respondents are always accepting (ready) work with new information and give them use their ability (creativity) while researching to achieve the goal.

Table 13. Frequency of innovative decision making

\begin{tabular}{|c|c|c|c|c|c|c|c|c|}
\hline \multirow{2}{*}{ No. } & \multirow{2}{*}{ Innovation Decision Making } & \multicolumn{5}{|c|}{ Frequency $(\%)$} & \multirow{2}{*}{ Mean } & \multirow{2}{*}{ Level } \\
\hline & & VD & $\mathrm{D}$ & $\mathrm{N}$ & A & VA & & \\
\hline 1 & $\begin{array}{l}\text { Readiness to accept and work } \\
\text { with new information. }\end{array}$ & 0.7 & 4.0 & 24.7 & 53.3 & 17.3 & 3.83 & High \\
\hline 2 & $\begin{array}{l}\text { Capacity to accept ambiguity } \\
\text { in decision making. } \\
\text { (uncertainty coping). }\end{array}$ & 0.7 & 5.3 & 26.0 & 54.7 & 13.3 & 3.75 & High \\
\hline 3 & $\begin{array}{l}\text { Willingness to commit to a } \\
\text { solution. (risk acceptance) }\end{array}$ & 0.7 & 6.7 & 23.3 & 56.0 & 13.3 & 3.75 & High \\
\hline 4 & $\begin{array}{l}\text { Ability to use creativity or } \\
\text { logic as appropriate. (brain } \\
\text { holism) }\end{array}$ & 0 & 5.3 & 18.0 & 64.7 & 12.0 & 3.83 & High \\
\hline \multicolumn{7}{|c|}{ Total means score } & 3.79 & High \\
\hline
\end{tabular}

\subsubsection{Total Mean Score for Ethical Work Climate}

In this section, the researcher summarizes the level of ethical work climate among respondents. Determination level of ethical work climate in the organization in an organization is based on three dimensions of ethical work climate in Section B. Mean score for each dimension is calculated to obtain the total mean score and finally determine the level of ethical work climate among researchers at University XYZ.

Table 14. The overall mean score for dimensions of the ethical work climate

\begin{tabular}{lcc}
\hline Dimension of Ethical Work Climate & Mean Score Perception & Level \\
\hline Caring Climate & 3.99 & High \\
Independence Climate & 3.79 & High \\
Mastery Climate & 3.96 & High \\
Total mean score & 3.91 & High \\
\hline
\end{tabular}

Table 14 above shows the dimension of ethical work climate, overall mean score for each dimension and level of each ethical work climate that encourages innovation. Based on Table 14 its shows all three aspects are high level, but the instrumental climate was the least perceived by the respondent with mean 3.79. The highest ethical work climate that implements is the caring climate with mean 3.99. The result shows that the ethical work climate among 
researchers at University $\mathrm{XYZ}$ is in a high level of implementation. It confirmed by the fact that the overall mean score for ethical work climate is 3.91 .

\subsubsection{Total Mean Score for Organizational Innovation}

In this section, the researcher summarizes the level of organizational innovation among respondents. The measurement of organizational innovation is based on three dimensions of organizational innovation in Section C. Mean score for each dimension is calculated to obtain the total mean score so that the researcher can finally determine the level of organizational innovation among researchers at University XYZ.

Table 15. The overall mean score for dimensions of organizational innovation

\begin{tabular}{lcc}
\hline \multicolumn{1}{c}{$\begin{array}{c}\text { Dimension of Organizational } \\
\text { Innovation }\end{array}$} & Mean Score Perception & Level \\
\hline Strategic Innovation & 3.39 & Moderate \\
Behavioural Innovation & 3.62 & Moderate \\
Innovative Decision making & 3.79 & High \\
Total mean score & 3.60 & Moderate \\
\hline
\end{tabular}

Table 15 shows the level of innovation perceived by most respondents about their organizations. Based on the study, generally, these researchers (academic staff) have a moderate level of innovation. It is shown by the fact that the total mean score for overall organizational innovation is 3.60 .

\subsubsection{Objective 2: To identify the relationship of ethical work climate and the organization innovation among researchers at University XYZ.}

\subsubsection{Normality Analysis}

Normality test was used to determine whether the data collected was normal or not (Bishara \& Hittner, 2012). The significant value of $\mathrm{P}$ is 0.05 , which represented $5 \%$. Parametric was used when the data normal (significant value higher than 0.05 or $\mathrm{p}>.05$ ) and the non-parametric test was used when the data not normal (a significant value smaller than 0.05 or $\mathrm{p}<.05$ ). If the data was normally distributed, Pearson correlation test would be used. Meanwhile, if the data is not normally distributed, Spearman correlation test will be used.

In this study, the factors were computed and tested whether they were normal or not. Kolmogorov-Smirnov Test and Shapiro-Wilk have used for testing the normality of data. If the sample size is larger than 50, the Kolmogorov-Smirnov test should be used. However, if the sample size were 50 or less, Shapiro-Wilk would yield a better result. As these research respondents are 294, hence Kolmogorov-Smirnov test is used. Table 16 below shown the result which is all significant value is $\mathrm{p}-0.00$, smaller than $0.05(\mathrm{p}<.05)$. This show the data is not normally distributed; hence Spearman correlation test will be used.

Table 16. Analysis of Normality

\begin{tabular}{lccc}
\hline & \multicolumn{3}{c}{ Kolmogorov-Smirnov } \\
\cline { 2 - 4 } & Statistic & DF & Sig. \\
\hline Caring climate & 0.104 & 294 & 0.000 \\
Independence climate & 0.131 & 294 & 0.000 \\
Mastery climate & 0.156 & 294 & 0.000 \\
Strategic innovation & 0.128 & 294 & 0.000 \\
\hline
\end{tabular}




\begin{tabular}{lccc}
\hline Behavioural innovation & 0.112 & 294 & 0.000 \\
Innovation decision making & 0.218 & 294 & 0.000 \\
\hline
\end{tabular}

\subsubsection{Correlation analysis}

The correlation coefficient is a statistical measure that calculates the strength of the relationship between the relative movements of the two variables. Table 17 below is the Rule of Thumb for Interpreting the Size of a Correlation Coefficient by Hinki, Wiersma, and Jurs (2003).

Table 17. Rule of Thumb for Interpreting the Size of a Correlation Coefficient

\begin{tabular}{cl}
\hline \multicolumn{1}{c}{ Size of Correlation } & \multicolumn{1}{c}{ Interpretation } \\
\hline 0.90 to $1.00(-0.90$ to -1.00$)$ & Very high positive (negative) correlation \\
0.70 to $0.90(-0.70$ to -0.90$)$ & High positive (negative) correlation \\
0.50 to $0.70(-0.50$ to -0.70$)$ & Moderate positive (negative) correlation \\
0.30 to $0.50(-0.30$ to -0.50$)$ & Low positive (negative) correlation \\
0.00 to $0.30(-0.00$ to -0.30$)$ & Little if any correlation \\
\hline
\end{tabular}

Table 18. Correlations between dimensions of ethical work climate and overall organizational

\begin{tabular}{|c|c|c|c|c|c|}
\hline & & $\begin{array}{c}\text { Overall } \\
\text { Innovation }\end{array}$ & $\begin{array}{c}\text { Caring } \\
\text { Climate }\end{array}$ & $\begin{array}{c}\text { Independence } \\
\text { Climate }\end{array}$ & $\begin{array}{l}\text { Mastery } \\
\text { Climate }\end{array}$ \\
\hline \multirow{4}{*}{$\begin{array}{l}\text { Overall } \\
\text { Innovation }\end{array}$} & Spearman & 1.000 & $.486 * *$ & $.331 * *$ & $.526 * *$ \\
\hline & Correlation & & & & \\
\hline & Sig. & & .000 & .000 & .000 \\
\hline & $\mathrm{N}$ & 294 & 294 & 294 & 294 \\
\hline \multirow{4}{*}{$\begin{array}{l}\text { Caring } \\
\text { Climate }\end{array}$} & Spearman & $.486 * *$ & 1.000 & $.446 * *$ & $.600 * *$ \\
\hline & Correlation & & & & \\
\hline & Sig. & .000 & . & .000 & .000 \\
\hline & $\mathrm{N}$ & 294 & 294 & 294 & 294 \\
\hline \multirow{3}{*}{$\begin{array}{l}\text { Independen } \\
\text { ce Climate }\end{array}$} & Spearman & $.331 * *$ & $.446 * *$ & 1.000 & $.353 * *$ \\
\hline & $\begin{array}{l}\text { Correlation } \\
\text { Sig. }\end{array}$ & .000 & .000 & 0 & .000 \\
\hline & $\mathrm{N}$ & 294 & 294 & 294 & 294 \\
\hline \multirow{4}{*}{$\begin{array}{l}\text { Mastery } \\
\text { Climate }\end{array}$} & Spearman & $.526 * *$ & $.600 * *$ & $.353 * *$ & 1.000 \\
\hline & Correlation & & & & \\
\hline & Sig. & .000 & .000 & .000 & . \\
\hline & $\mathrm{N}$ & 294 & 294 & 294 & 294 \\
\hline
\end{tabular}

$* *$ Correlation is significant at the 0.01 level (2-tailed)

Analysis of the findings in this section is based on the 2nd objective which was built in the early stage of the study. Table 18 above indicate the results of Spearman correlation toward the relationship of ethical work climate dimensions toward overall innovation. The findings showed that each dimensions of ethical work climate have different strength of association toward overall innovation.

The first dimensions indicated that there is a positive direction on the low association between caring climate toward overall innovation where the correlation coefficient obtained is $\mathrm{r}=0.486$, sig. $=0.00<0.05$. Whereas the second dimension obtained a correlation coefficient 
$r=0.331$, sig. $=0.00<0.05$. The finding indicated that there is a positive direction on the low association between independence climates toward overall innovation. Finally, the last dimension, the correlation coefficient obtained is $r=0.526$, sig. $=0.00<0.05$ indicated that there is a positive direction on a moderate association between mastery climate toward overall innovation. 
Table 19 below shows Correlations between overall ethical work climate and overall organizational innovation.

Table 19. Correlations between overall ethical work climate and overall organizational

\begin{tabular}{|c|c|c|c|}
\hline & & $\begin{array}{l}\text { Overall Organization } \\
\text { Innovation }\end{array}$ & $\begin{array}{l}\text { Overall Ethical } \\
\text { Work Climate }\end{array}$ \\
\hline \multirow{3}{*}{$\begin{array}{l}\text { Overall Organization } \\
\text { Innovation }\end{array}$} & Spearman Correlation & 1.000 & $5.76^{* *}$ \\
\hline & Sig. &. & .000 \\
\hline & $\mathrm{N}$ & 294 & 294 \\
\hline \multirow{3}{*}{$\begin{array}{l}\text { Overall Ethical Work } \\
\text { Climate }\end{array}$} & Spearman Correlation & $5.76 * *$ & 1.000 \\
\hline & Sig. & .000 & . \\
\hline & $\mathrm{N}$ & 294 & 294 \\
\hline
\end{tabular}

\footnotetext{
*** Correlation is significant at the 0.01 level (2-tailed)
}

Overall ethical work climate showed significant positive relation with overall innovation which positive direction on moderate correlation coefficient, $r=0.576$, sig. $=0.000$. The findings of the analysis above showed that implementation of caring climate, independence climate and mastery climate in the selected research institutes significantly related to innovation. Through the statistic and analysis above, the research objectives for 2 nd objective have achieved.

\section{Discussion and recommendation}

\subsection{Discussion}

The primary goal of this study is to identify the relationship between ethical work climate and organizational innovation among researchers at University XYZ. To achieve the goal, the researcher has been established the two objectives of the study.

\subsubsection{Discussion on 1st Objective: To investigate the level of ethical work climate and the level of organizational innovation among researchers at University XYZ}

Based on the research findings, the dimension of ethical work climate that is highly implemented is caring climate with mean 3.99. The caring climate is a positive attitude that might result in several advantages including commitment, dedication to work, cooperation and fair competitiveness in the workplace. Most researchers that involved in research, they believe that their organization has implemented high caring ethical climate. As we know when people have a high commitment to work, it can encourage innovation.

For mastery climate, the mean score is 3.96. Meanwhile, the lowest mean score is independence climate with 3.79. Although the mean score for instrumental is the smallest, overall implementation of ethical work climate is still high which got a 3.91 mean score. It may be perhaps that the ethical work climate has been fixed in the mind of researchers (academic staff) at University XYZ and these work values has well adopted by researches no matter race, age, group and gender across University XYZ.

Next, two from three dimensions of innovation gain moderate level. The range of the mean score is from 3.39 to 3.79 . In this study, strategic innovation had obtained the lowest mean score which is 3.39 (moderate level). Even though mostly level is moderate, and the total mean score of overall dimensions of organizational innovation is a moderate level which 
is 3.60 , it still showed innovation in their organization in conducting research still yet efficient.

According to Kumar and Rose (2010) research, their findings to the present study are consistent with previous research which is the previous study reported that their subjects were highly committed to the work ethic. Even though the study was in an Islamic setting and have different variables, it still measuring morale. Hence, based on my research the conclusion that can be made is present study together with the previous study shown that ethical work climate remains superior and acknowledged in organizations [27].

\subsubsection{Discussion on 2nd Objective: To identify the relationship between ethical work climate and organizational innovation among researchers at University XYZ}

To identify the relationship between ethical work climate and organizational innovation among researchers at University XYZ, Spearman correlation test were conducted. Below Table 20 show a summary result of ethical work climate and overall innovation hypothesis.

Table 20. Summary results of ethical work climate and overall innovation hypothesis.

\begin{tabular}{lcccc}
\multicolumn{1}{c}{ Hypothesis } & Correlation & $\begin{array}{c}\text { Sig. } \\
\text { Level }\end{array}$ & $\begin{array}{c}\text { Null } \\
\text { Hypothesis } \\
\left(\mathrm{H}_{0}\right)\end{array}$ & $\begin{array}{c}\text { Alternative } \\
\text { Hypothesis } \\
\left(\mathrm{H}_{1}\right)\end{array}$ \\
\hline Caring Climate $\rightarrow$ Overall innovation & 0.486 & 0.000 & Reject & Accept \\
Independence Climate $\rightarrow$ Overall innovation & 0.331 & 0.000 & Reject & Accept \\
Mastery Climate $\rightarrow$ Overall innovation & 0.526 & 0.000 & Reject & Accept \\
\hline
\end{tabular}

H0: There is no significant relationship

H1: There is a significant relationship

In Figure 1 (conceptual framework), hypothesis 1 stated there is a significant relationship between ethical work climate and organizational innovation. For summary based on Table 19 (Correlations between overall ethical work climate and overall organizational innovation) in Chapter 4, the strength of relationship between overall ethical work climate and overall organizational innovation is moderate positive correlation based in Table 17 (Rule of Thumb for Interpreting the Size of a Correlation Coefficient) with correlation coefficient of 0.576 and significant value of 0.00 . Therefore, in conclusion for hypothesis 1 (Figure 1, conceptual framework) is, there is a moderate relationship between ethical work climate and organizational innovation among researchers at University XYZ.

In Figure 1 (conceptual framework), hypothesis 2 stated there is a significant relationship between caring climate and organizational innovation. Based in Table 19, assumption 2 which is the correlation between caring climate and overall innovation is 0.486 (positive). Moreover, the significant value is 0.00 which smaller than the stated considerable level of 0.05 . Hence based on Table 17 (Rule of Thumb for Interpreting the Size of a Correlation Coefficient), the strength of the relationship is a low positive correlation, so these two variables are related. Therefore, H0 is rejected and H1 is accepted. In conclusion for hypothesis 2 is, there is a low positive relationship between caring climate and overall innovation.

Next, in Figure 1 (conceptual framework), hypothesis 3 stated there is a significant relationship between independence climate and organizational innovation. Based in Table 18, the assumption 3 which is the correlation between independence climate and overall innovation is 0.331 (positive). Moreover, the significant value is 0.00 which smaller than the stated significant level of 0.05 . Hence based on Table 17 (Rule of Thumb for Interpreting the Size of a Correlation Coefficient), the strength of the relationship is a low positive correlation, 
so these two variables are related. Therefore, H0 is rejected and H1 is accepted. In conclusion for hypothesis 3 is, there is a low positive relationship between independence climate and overall innovation.

In Figure 1 (conceptual framework), hypothesis 4 stated there is a significant relationship between mastery climate and organizational innovation. Based in Table 18, the assumption four which is the correlation between mastery climate and overall innovation is 0.526 (positive). Moreover, the significant value is 0.00 which smaller than the stated significant level of 0.05 . Hence based on Table 17 (Rule of Thumb for Interpreting the Size of a Correlation Coefficient), the strength of the relationship is a low positive correlation, so these two variables are related. Therefore, $\mathrm{H} 0$ is rejected and $\mathrm{H} 1$ is accepted. In conclusion for hypothesis 4 is, there is a low positive relationship between mastery climate and overall innovation.

Assumptions of the findings probably due to organizational innovation among academician staff that involves in research at University XYZ is not directly building on each dimension of ethical work climate but developed based on the overall of the ethical work climate. This is supported in Suib and Said (2017) that citation of Kumar \& Rose [27] research, which is even though there are high implementation of work ethics in his study, it might not contribute much to innovation capability because there are many factors that contribute equally to innovation capability such as human capital, internal and external structures.

\subsection{Limitation}

The limitation of this research is the population selected is only in University XYZ faculty (consist of six faculties) which exclude University XYZ of another branch. There are two branches of University XYZ. In this research, the selected population is academician staff. As my research focuses on the researcher (respondent), the selected population must in criteria of academician staff that involve in research and part from either one of six faculties in University XYZ.

\subsection{Recommendation}

To expand the scope of the study, it is recommended to conduct the same research on another branch. So then, they will be finding out other factors that influence organizational innovation. For the academician staff, my recommendation is to have a chance to find out the element of ethical work climate that influences organizational innovation while involving in research. This is because they will able to improve their selves in term of ethical work climate that leads to promote their organizational innovation.

Lastly, for the future researcher, my recommendation is this study should collect data from another research university in Malaysia. This is because future researches with data from various research universities are a good way to verify whether the results of this study would hold.

\subsection{Conclusion}

This study shows a significant relationship between ethical work climate and organizational innovation level. The analysis proves that ethical work climate has an influence on innovation level. In conclusion, in today's rapid competitive world, organizations need to have a set of distinctive ethical standards and values and an organization-specific ethical climate. The organization, especially top management, should recognize the importance of 
innovation and should work harder to achieve and improve it. Organizations that adopt an ethical climate and manage to increase innovation will survive in the long term.

\section{References}

[1] N. Shahroom, A. A., \& Hussin, "Industrial Revolution 4.0 and Education," Int. J. Acad. Res. Bus. Soc. Sci., vol. 8, no. 9, 2018.

[2] A. Ahmed, S., \& Ahmed, "Employee innovation: management practices affecting the innovative behavior at workplaceNo Title," 3rd Islam. Ctries. Conf. Stat. Sci. Stat. Better Life, 2015.

[3] K. Lilly, J., Duffy, JA \& Wipawayangkool, "Impact of ethical climate on organizational trust and the Role of Business Performance," J. Appl. Behav. Manag., vol. 17, no. 1, pp. 33-49, 2016.

[4] M. Shahzad, F., Xiu, G., \& Shahbaz, "Organizational culture and innovation performance in Pakistan's software industry," Technol. Soc., vol. 51, pp. 66-73, 2017.

[5] M. Cavus, M.F., \& Bicer, "Relationship between Organizational Ethical Climate and Innovative Behavior: An Example from Turkey, International Journal of Academic Research in Business and Social Sciences," Hum. Resour. Manag. Acad. Res. Soc. Int. J. Acad. Res. Bus. Soc. Sci., vol. 6, no. 10, pp. 117-127, 2016.

[6] K. Oluwatayo, Gbenga \& Fidelis Chinedu, Onwunyili \& Janet A, "Unethical Assessment Practices among University Lecturers in Anambra State: Undergraduates' Perspective," Int. J. Educ. Res. Dev., vol. 5, pp. 34-41, 2015.

[7] O. Factbook, Economic, environmental and social statistics. Paris: OECD, 2014.

[8] J. B. Victor, B., \& Cullen, "The Organizational Bases of Ethical Work Climates," Adm. Sci. Quarterly, vol. 33, no. 1, p. 101, 1988.

[9] O. Hernaus, T., Dysvik, A., \& Behaviour, "The role of multilevel synergistic interplay among team mastery climate, knowledge hiding, and job characteristics in stimulating innovative work behavior," vol. 27, no. 2, pp. 281-299, 2017.

[10] F. Chouaib, A., \& Zaddem, "The Ethical Climate at Work. RIMHE: Revue Interdisciplinaire Management, Homme(s) \& Entreprise," vol. 9, no. 5, p. 15, 2013.

[11] B. H. Fritzsche D., "Linking Management Behavior to Ethical Philosophy: An Empirical Investigation," Acad. Manag. Journal, pp. 166-175, 1984.

[12] J. B. Martin, K. D., \& Cullen, "Continuities and Extensions of Ethical Climate Theory: A Meta-Analytic Review,”. J. Bus. Ethics, vol. 69, no. 2, pp. 175-194, 2006.

[13] B. Cullen, J., Parboteeah, K. \& Victor, "The Effects of Ethical Climates on Organizational Commitment: A Two-Study Analysis," J. Bus. Ethics., vol. 46, 2003.

[14] M. Newland, A., Newton, M., Stark, A., Podlog, L., \& Hall, "College students' perceptions of a caring climate in group physical activity classes," Biomed. Hum. Kinet., vol. 9, no. 1, pp. 99-106, 2017.

[15] L. Manroop, "Human resource systems and competitive advantage," An ethical Clim. Perspect., vol. 24, no. 2, pp. 186-204, 2015.

[16] W. Nafei, "The Influence of Ethical Climate on Job Attitudes: A Study on Nurses in Egypt.,". Int. Bus. Res., vol. 8, no. 2, 2015.

[17] C. Ames, Achievement Goals, Motivational Climate, and Motivational Processes. In G. Roberts (Ed.), Motivation in Sport and Exercise. Human Kinetics Publishers., 1992.

[18] et al. Cerne, M., Nerstad, C., Dysvik, A., "What Goes around Comes around: Knowledge Hiding, Perceived Motivational Climate, and Creativity.," Acad. Manag. Journal, vol. 57, pp. 172-192, 2014. 
[19] K. Hastie, P. A., Rudisill, M. E., \& Boyd, "An ecological analysis of a preschool mastery climate physical education programme.," Phys. Educ. Sport Pedagog., vol. 21, no. 2, pp. 217-232, 2016.

[20] A. T. Karabulut, "Effects of Innovation Strategy on Firm Performance: A Study Conducted on Manufacturing Firms in Turkey.No Title," Procedia -Social Behav. Sci., vol. 195, pp. 1338-1347, 2015.

[21] G. P. Pisano, "You Need an Innovation Strategy the Big Idea.," Harvard Bus. Rev., vol. 93, pp. 44-54, 2015.

[22] R. Gevers, J. M. P., van Eerde, W., \& Roe, "The innovative Work Behavior Concepts; definition and orientation," Gedrag En Organ., vol. 27, no. 1, pp. 5-18, 2014.

[23] U. of S. California, Quantitative methods. 2015.

[24] D. W. Krejcie, R.V., \& Morgan, "Determining sample size for research activities.," Educ psychol meas., 1970.

[25] P. George, D., \& Mallery, SPSS for Windows step by step: A simple guide and reference 11.0 update (4th ed.). Boston: Allyn \& Bacon, 2033.

[26] N. Kassim, Sharmila and Tasmin, Rosmaini and Che Rusuli, Muhamad Saufi and Hashim, Level of technological knowledge management adoption and its relation to firm's innovativeness. Melaka, 2011.

[27] R. C. Kumar, N. \& Rose, "Examining the link between Islamic work ethic and innovation capability," J. Manag. Dev., vol. 29, no. 1, pp. 79-93, 2010. 